\title{
Article
}

\section{Fire protection of light and massive timber elements using gypsum plasterboards and wood based panels: A large-scale compartment fire test}

Kolaitis, Dionysios, Asimakopoulou, Eleni and Founti, Maria

Available at http://clok.uclan.ac.uk/31939/

Kolaitis, Dionysios, Asimakopoulou, Eleni ORCID: 0000-0001-5644-1372 and Founti, Maria (2014) Fire protection of light and massive timber elements using gypsum plasterboards and wood based panels: A large-scale compartment fire test. Construction and Building Materials, 73 . pp. 163-170. ISSN 0950-0618

It is advisable to refer to the publisher's version if you intend to cite from the work. http://dx.doi.org/10.1016/j.conbuildmat.2014.09.027

For more information about UCLan's research in this area go to http://www.uclan.ac.uk/researchgroups/ and search for <name of research Group>.

For information about Research generally at UCLan please go to http://www.uclan.ac.uk/research/

All outputs in CLoK are protected by Intellectual Property Rights law, including Copyright law. Copyright, IPR and Moral Rights for the works on this site are retained by the individual authors and/or other copyright owners. Terms and conditions for use of this material are defined in the policies page. 


\title{
Fire Protection of Light and Massive Timber Elements using Gypsum Plasterboards and Wood Based Panels: A Large-Scale Compartment Fire Test
}

\author{
Dionysios I. Kolaitis $^{1,2 *}$, Eleni K. Asimakopoulou ${ }^{1}$ and Maria A. Founti ${ }^{1}$ \\ ${ }^{1}$ Laboratory of Heterogeneous Mixtures and Combustion Systems, Thermal Engineering Section, \\ School of Mechanical Engineering, National Technical University Athens, \\ Heroon Polytechniou 9, Polytechnioupoli Zografou, 15780 Athens, Greece \\ *Corresponding author: e-mail: dkol@ cental.ntua.gr, Tel. +30-210-7724002, Fax. +30-210-7723527 \\ ${ }^{2}$ Greek Fire Academy, \\ Matsa 32, 14564 Kifisia, Greece
}




\begin{abstract}
A full-scale compartment fire test was performed to assess gypsum plasterboards and wood based panels as cladding materials for the fire protection of light and massive timber elements. The test compartment was constructed using both the Timber Frame and the Cross Laminated Timber techniques; a wood crib was used to achieve realistic fire conditions. Temperature measurements and optical inspection evidence suggested that gypsum plasterboards offered adequate fire protection since they did not fail and no charring was observed in the timber elements. A free standing wall inside the test compartment, protected by wood-based panels, partially collapsed. Measured values of characteristic failure times, such as time to failure of fire protection cladding and time to onset of charring, were compared to relevant Eurocode correlations, achieving good levels of agreement. The obtained set of measurements, describing the time evolution of a large variety of physical parameters, such as gas and wall layer temperatures, can be used for validation of relevant advanced fire simulation tools.
\end{abstract}

Keywords: Timber Frame, Cross Laminated Timber, CLT, Gypsum Plasterboard, Wood Based Panels, Fire Protection, Timber Construction, Compartment Fire Test

\title{
1. Introduction
}

Timber construction offers a range of advantages in terms of cost, time for construction, energy efficiency and sustainability [1]; it is also capable of exhibiting high anti-seismic and firesafety performance, which is at least on par with "massive" construction techniques (e.g. reinforced concrete) [SP Report 2010]. Since raw wood is essentially a solid fuel, fire safety regulations dictate the use of fire protection means for timber elements, aiming to reach the required levels of fire resistance (e.g. load bearing function, integrity). Fire protection of timber elements is commonly achieved either by the application of fire retarding agents (e.g. intumescent coatings, impregnation) or by the installation of fire protecting claddings on the "fire exposed" side of the elements. The most common materials used as fire protection claddings are gypsum plasterboards (GP) and wood-based panels (WBP) [2].

Gypsum plasterboards are extensively used as a fire protection cladding for timber construction [2,3]. A typical gypsum plasterboard consists essentially of a gypsum layer sandwiched between two heavy paper sheets. The crystal lattice of raw gypsum $\left(\mathrm{CaSO}_{4} \cdot 2 \mathrm{H}_{2} \mathrm{O}\right)$ contains approximately $21 \%$ by weight chemically bound water. When exposed to an increasing temperature environment, calcium sulphate di-hydrate $\left(\mathrm{CaSO}_{4} \cdot 2 \mathrm{H}_{2} \mathrm{O}\right)$ undergoes two endothermic decomposition reactions during which the chemically bound water dissociates from the crystal 
lattice and evaporates. This process, known as "gypsum dehydration" (or "calcination"), occurs in the temperature region between $90^{\circ} \mathrm{C}$ and $250^{\circ} \mathrm{C}$. Gypsum chemical decomposition (dissociation of the chemically bound water) occurs in two stages [4]. In the first stage, calcium sulphate di-hydrate $\left(\mathrm{CaSO}_{4} 2 \mathrm{H}_{2} \mathrm{O}\right)$ loses $75 \%$ of its water, thus forming calcium sulphate hemihydrate $\left(\mathrm{CaSO}_{4} \cdot \frac{1}{2} \mathrm{H}_{2} \mathrm{O}\right)$. If gypsum is further heated, a second reaction occurs, where the calcium sulphate hemi-hydrate loses the remaining water to form calcium sulphate anhydrite $\left(\mathrm{CaSO}_{4}\right)$. Both reactions are endothermic, requiring large amounts of energy to be completed. Therefore, heat transfer through gypsum plasterboards is practically impeded until the dehydration process is complete; the advanced fire resistance characteristics of gypsum plasterboards are mainly owed to this effect.

In the current study, the fire protection potential of gypsum plasterboards and wood-based panels for light and massive timber elements is comparatively assessed. A large-scale compartment fire test is performed; temperatures at various depths of the multi-layered wall assemblies are continuously monitored, aiming to thoroughly investigate the thermal behaviour of timber elements and the respective fire protection claddings.

\subsection{Light and Massive Timber Element Construction}

Two contemporary timber construction techniques are employed in this study, namely the Timber Frame (TF) and the Cross Laminated Timber (CLT) system. The timber frame system is used worldwide (e.g. N. America, Japan, N. Europe) for the construction of load-bearing wall and floor assemblies, especially in the case of low-rise buildings. The timber frame system is based on light timber structural members of rectangular cross-section (studs, battens) that provide a stable frame to which interior and exterior walls are attached. The timber frame is covered by a variety of sheathing panels (e.g. plywood, oriented strand boards, medium density fibreboards, particleboards, chipboards), whereas the air cavities formed between the TF members are usually filled with thermal and acoustic insulation materials.

The CLT system, also known as Glued Laminated Timber, Glulam or XLam, is a relatively new timber construction technique used for the construction of mid- and high-rise buildings, which is becoming increasingly popular in certain regions (e.g. Austria, Italy, N. America). The CLT system is based on prefabricated massive timber panels, consisting of 3 to 7 timber layers stacked crosswise (typically at 90 degrees) and glued together; the thickness of each individual timber layer ranges from $10 \mathrm{~mm}$ to $50 \mathrm{~mm}$ and its width may vary from $60 \mathrm{~mm}$ to $240 \mathrm{~mm}$. The CLT panels are used to construct load-bearing wall or floor assemblies. The CLT system offers a range of advantages over the timber frame system, such as higher in-plane and out-of-plane 
strength and stiffness, better air tightness and lower risk of fire spreading due to the absence of air cavities. Due to the inherent nature of thick timber members to char slowly and at a predictable rate, massive timber systems can maintain significant structural resistance for an extended period of time when exposed to fire [5]. CLT panels have the potential to provide excellent fire resistance characteristics, often comparable to typical massive assemblies of non-combustible construction. However, the CLT panels may increase the total fire load; the addition of a fire protection cladding at the exposed side increases the overall fire resistance rating of the system.

\subsection{Large-Scale Compartment Fire Tests of Protected Timber Structures}

Standard fire resistance tests of wall assemblies are conducted under rigorously controlled furnace conditions, using gaseous fuel burners to reproduce the ISO 834 temperature-time curve [6]. The increasing interest in CLT construction has stimulated a number of studies focusing on the behaviour of CLT elements when exposed to a standard fire resistance test [7-11]. However, results obtained in fire resistance furnaces may not be representative of realistic fire scenarios, where wall assemblies are not actually heated in a uniform or continuous manner [12]. On the other hand, natural fire tests, where "solid fuel packages" (e.g. wood cribs or real furniture items) are used, create more realistic fire conditions. Despite the increasing number of experimental studies on natural fire tests in large scale compartments [13-16], there are few relevant literature reports focused on the fire behaviour of load-bearing CLT elements.

A series of fire experiments in a full-scale compartment has been performed by VTT [17], using both light and massive timber construction techniques. It was demonstrated that when gypsum plasterboards are used as a fire protection cladding, heat flux to the timber structure is dramatically (90\%-97\%) reduced and the onset of charring is considerably delayed (by 20-40 min). In addition, the use of gypsum plasterboards cladding was found to result in higher compartment gas temperatures and lower probability of external flaming; the Eurocode correlation [18] was found to significantly over-predict the measured indoor air temperatures by $300-500^{\circ} \mathrm{C}$. A large-scale natural fire test has been performed by the CNR-IVALSA group on a three-storey CLT building [19]. The $10 \mathrm{~m}$ high building was exposed to a typical residential fire scenario; gypsum plasterboard protection was found to limit the observed charring depth in the CLT panels. A very systematic study, comprising 5 full-scale compartment fire tests using protected and unprotected CLT panels, has been recently performed in Carleton University [20]. It was observed that protected CLT panels exhibited no noticeable contribution to the fire load, while unprotected CLT panels delaminated and had a significant contribution to the total fire load of the compartment. 
The main scope of the current study is to evaluate the effectiveness of gypsum plasterboards and wood-based panels as fire protection claddings for timber construction, using either light or massive timber elements; towards this end, a natural fire test is performed in a full-scale compartment where both timber frame and CLT construction systems are simultaneously used. In addition, the extensive set of measurements obtained during the test is intended to serve as a detailed validation suite for relevant fire simulation tools.

\section{Experimental Methodology}

\subsection{General Layout of the Test Compartment}

The internal dimensions of the test compartment are $2220 \mathrm{~mm}$ x $2220 \mathrm{~mm}$ x $2110 \mathrm{~mm}$. An open window, measuring $430 \mathrm{~mm}$ x $980 \mathrm{~mm}$, provides the required ventilation (Fig. 1). The window is located on the S side; the distance of the window sill from the compartment's floor is $940 \mathrm{~mm}$. A fire-protected door is installed at the $\mathrm{E}$ wall to facilitate access to the fire compartment; the door is closed during the test. Aiming to simultaneously investigate the fire behaviour of two timber construction systems, a symmetrical layout is selected; timber frame is used in two vertical walls (E, S) and the ceiling, whereas CLT is used in the remaining vertical walls (W, N) and the floor. The installation of the fire protection claddings (e.g. spacing of fasteners) is performed in accordance with the Eurocode 5 [2] design guidelines.

\subsection{Detailed Construction of the Wall Assemblies}

Rectangular ( $85 \mathrm{~mm}$ x $40 \mathrm{~mm}$ ) cross-section timber studs and battens are used to construct the basic frame of the timber frame wall assemblies, with $10 \mathrm{~mm}$ thick plywood panels serving as the sheathing layer; the closed cavities created by the timber frame are filled with an $85 \mathrm{~mm}$ layer of rock wool (Fig. 2, left). The CLT wall assemblies are formed using pre-fabricated 5-layer CLT panels, $95 \mathrm{~mm}$ thick; rectangular $(40 \mathrm{~mm}$ x $85 \mathrm{~mm}$ ) wood studs on the indoor side provide the frame for installing a $40 \mathrm{~mm}$ rock wool layer (Fig. 2, middle). In both timber frame and CLT wall assemblies, a final fire protection cladding layer, consisting of two $12.5 \mathrm{~mm}$ fire-resistant (type DF) gypsum plasterboard panels, is installed on the indoor side. A double layer of $12.5 \mathrm{~mm}$ fireresistant gypsum plasterboard panels is also used for the internal lining of the floor and the ceiling; in this case, an additional fire-resistant chipboard panel, $16 \mathrm{~mm}$ thick, is installed beneath the gypsum plasterboard layers to reinforce their mechanical strength. 
In addition, a free standing wood-based panels wall, measuring $800 \mathrm{~mm}$ x $2000 \mathrm{~mm}$ is constructed inside the test compartment, using the timber frame technique (Fig. 1). Multiple layers of fire-resistant engineered timber panels are used in the TF-WBP wall assembly; it consists, from the $\mathrm{N}$ to the $\mathrm{S}$ side, of two layers of $16 \mathrm{~mm}$ fire resistant (Euroclass $\mathrm{B}-\mathrm{s} 2, \mathrm{~d} 0$ ) chipboard, one layer of $10 \mathrm{~mm}$ plywood, the $85 \mathrm{~mm}$ x $40 \mathrm{~mm}$ timber studs combined with $85 \mathrm{~mm}$ rock wool, one layer of $10 \mathrm{~mm}$ plywood and two layers of $16 \mathrm{~mm}$ fire resistant (Euroclass $\mathrm{C}-\mathrm{s} 3$, d0) MDF (Fig. 2, right). The chipboard panels, due to their higher reaction to fire rating compared to the MDF panels, are installed at the northern side of the free standing wall, which lies closer to the fire load.

\subsection{Fire Load}

In natural fire large-scale compartment fire tests, the fire load is commonly simulated using wood cribs [17, 19, 21, 22]. Wood cribs exhibit a range of advantages over real furniture, such as enabling sufficient air entrainment in the fire load and intensifying the levels of heat transfer and turbulent mixing [23]. Consequently, a wood crib is selected for the current study.

The design fire load density is estimated following the methodology described in Eurocode 1 [18], assuming a typical office room $\left(420 \mathrm{MJ} / \mathrm{m}^{2}\right)$. The fire load is simulated using $105 \mathrm{~kg}$ of fir wood; its lower heating value $(19.87 \mathrm{MJ} / \mathrm{kg})$ was measured, according to the ISO 1716 standard [24], using a Parr 6200 isoperibolic oxygen bomb calorimeter. The wood crib assembly, measuring $900 \mathrm{~mm}$ x $1200 \mathrm{~mm}$ x $660 \mathrm{~mm}$, is placed at the NE corner of the room, in such a way as to provide uniform thermal exposure conditions to the adjacent timber frame (E) and CLT (N) walls (Fig. 1).

The fire ventilation conditions in the test compartment are estimated using a correlation for the calculation of the global equivalence ratio, GER $=\left(m_{f}^{\prime} r_{0} / m_{a}^{\prime} Y_{O 2, a i r}\right)$ [25]. The constant fuel mass loss rate, $m_{f}^{\prime}(\mathrm{kg} / \mathrm{s})$, is calculated by assuming complete combustion of the entire fire load at the end of the test (45 $\mathrm{min}$ ). For the oxygen to fuel stoichiometric mass ratio, the value of $r 0=1.52$, suggested in a relevant experimental study on wood crib compartment fires [26], is used. The mass flow rate of the entrained air, $m^{\prime}{ }_{a}(\mathrm{~kg} / \mathrm{s})$, is estimated using an empirical correlation, $m^{\prime}{ }_{a}=$ $0.52 A H^{1 / 2}$, where $A\left(\mathrm{~m}^{2}\right)$ is the total area of the opening and $H(\mathrm{~m})$ the opening height [27]. The calculated value of the global equivalence ratio, $G E R=1.17$, suggests that slightly underventilated fire conditions are developed in the test compartment. 


\subsection{Instrumentation}

An extensive set of measuring devices is installed in the test compartment, aiming to continuously monitor a broad range of physical parameters (Fig. 1). The obtained measurements allow a detailed description of the thermal behaviour of the multi-layered wall assemblies and of the main characteristics of the multi-component flow-field developing inside the test compartment.

Gas temperatures inside the test compartment are monitored using 14 chromel type K bare bead thermocouples, $1 \mathrm{~mm}$ in diameter, located in two thermocouple trees (Fig. 1), arranged at 7 different heights $(50,500,1000,1250,1500,1750$ and $1900 \mathrm{~mm}$ above the floor). The first thermocouple tree (TCT-NW) is installed near the NW corner of the test compartment, where, due to the presence of the TF-WBP free standing wall, combustion products are expected to accumulate. The second thermocouple tree (TCT-SE) is installed near the SE corner of the test compartment, close to the open window (Fig. 1). The used thermocouples exhibited a standard calibration uncertainty of $\pm 2.5^{\circ} \mathrm{C}$ between $-40^{\circ} \mathrm{C}$ and $333^{\circ} \mathrm{C}$ and of $0.75 \%$ for the temperature range $333^{\circ} \mathrm{C}$ to $1200^{\circ} \mathrm{C}$. Bare bead thermocouples installed at the interior of fire compartments are known to exhibit systematic errors owed to radiative heat transfer [13, 23, 28]. The recorded thermocouple data are corrected for radiation using a "post-processing" methodology [13, 23]. Details on the employed gas temperature measurement correction method are given in the Appendix.

Wall surface temperatures and temperatures at the interfaces between the various wall assembly layers are monitored using 15 type $\mathrm{K}$ thermocouples, installed at 3 representative timber frame, CLT and wood-based panel protected timber frame wall assemblies (Fig. 2). All thermocouples are installed at a height of $1490 \mathrm{~mm}$ from the floor; they are placed at the main interfaces between the various material layers. The coding used for naming the wall assembly temperature measurements comprises 3 parts; the first corresponds to the wall assembly type (TF, CLT, WBP), the second to whether the measured temperature refers to either the gaseous environment $(\mathrm{G})$ or the wall (W) and the third part indicates the distance (in $\mathrm{mm}$ ) of the thermocouple from the exposed surface of the wall assembly (Fig. 2). Aiming to describe in sufficient detail the dynamic behaviour of the developing thermal-field in the test compartment, a $5 \mathrm{~s}$ sampling rate is used for the gas and wall surface temperature measurements.

An infra-red camera, aimed through the window at the northern CLT wall, is used to monitor temperature variations at the exposed side of the wall. Flame shape and location are recorded using 3 high-definition video cameras installed at the corners of the test compartment (Fig. 1). A Madur GA40-Plus gas analyser is used to monitor variations in the gaseous concentrations of key 
species $\left(\mathrm{O}_{2}, \mathrm{CO}_{2}, \mathrm{CO}, \mathrm{SO}_{2}, \mathrm{NO}, \mathrm{NO}_{2}\right.$ and total $\mathrm{NO}$ ). The gas analyser probe is installed $300 \mathrm{~mm}$ below the ceiling (Fig. 1); a 25 s sampling rate is used. Finally, the vertical velocity of the gaseous products emanating from the upper part of the window is measured using a Pitot tube. The complete set of measured data can be found in a recent report [Pyrosbestikh, 2011].

\section{Results and Discussion}

\subsection{Fire Development}

Fire initiation is achieved by igniting a paraffin soaked fabric located under the crib. The fire is allowed to develop freely (natural fire), until the end of the test, $45 \mathrm{~min}$ after fire initiation, when it is suppressed. Table 1 summarises the observed major events and correlates them to representative measured average gas temperatures. A rapid increase of the fire power is observed during the initial fire growth stage; the gaseous temperature quickly reaches $750^{\circ} \mathrm{C}$. Approximately 9 min after fire initiation, there is a sudden decrease in the gas temperatures; a local minimum $\left(420^{\circ} \mathrm{C}\right)$ is reached at the 11 min mark. A sudden drop in oxygen concentration is simultaneously recorded at the same time period $(9-11 \mathrm{~min})$. This behaviour suggests that strongly under-ventilated fire conditions are temporarily established in the compartment, owed to the rapidly increasing concentrations of combustion products; however, the ambient air entrainment through the window results in a gradual increase of the indoors oxygen concentration, thus allowing gas temperatures to regain their previous levels, roughly $13 \mathrm{~min}$ after fire initiation. Approximately $17 \mathrm{~min}$ after fire initiation, the fire growth stage is completed and gas temperatures reach their peak values $\left(830^{\circ} \mathrm{C}\right)$. Fully developed fire conditions are then established that last until the end of the test. At the 21 min mark, the thermocouple tree installed near the SE corner (TCT-SE) failed. The S side of the TF-WBP free standing wall, partially collapsed approximately $35 \mathrm{~min}$ after fire initiation.

Temperature measurements across the timber frame and CLT wall assemblies, as well as postfire visual inspection, suggest that no charring occurs in any timber frame or CLT element; this is mainly attributed to the fact that the double gypsum plasterboard wall fire protection layer stays in place and does not collapse, despite the occasional cracking observed at the exposed side (Fig. 3). Even though a partial collapse of the exposed gypsum plasterboard layer protecting the ceiling is observed, the unexposed gypsum plasterboard layer remains intact, thus effectively protecting the timber frame ceiling assembly. Figure 3 also illustrates the collapse of the S side of the TFWBP wall, protected by a double layer of fire resistant MDF; its N side, covered by a double 
layer of fire resistant chipboard, stands in place. In the TF-WBP wall assembly, substantial charring is observed in the, eventually, unprotected timber studs.

\subsection{Gas Temperatures}

The time variation of radiation corrected gas temperatures, measured at both thermocouple tree locations, is presented in Fig. 4. A thermally stratified flow is quickly established in both cases; as expected, temperatures at lower heights $(50-500 \mathrm{~mm})$ are significantly lower than the respective upper layer gas temperatures $(1000-1900 \mathrm{~mm})$. In general, the initial fire growth stage ( 0 - $17 \mathrm{~min})$ is followed by the fully-developed fire stage (17 - $45 \mathrm{~min})$, where quasi-steady state conditions are established in the upper layer and the corresponding temperatures remain practically constant. During the fire growth stage, gas temperatures gradually increase and no distinct flashover event is observed. Qualitative characteristics are similar in both measuring locations; however, the recorded values of TCT-SE temperatures are relatively higher than their TCT-NW counterparts. This is mainly owed to the accumulation of gas products between the NW corner of the compartment and the TF-WBP free standing wall that results in the development of drastically different thermal conditions compared to that prevailing at the vicinity of the TCT-SE, which lies close to the open window (Fig. 1).

Oxygen concentration measurements, supported by video recordings of the flame, suggest that the sudden drop in the upper layer gas temperatures, observed after the initial fire growth stage (9 - $11 \mathrm{~min}$ ), is a result of local oxygen starvation due to the development of strong under-ventilated fire conditions. Gradual entrainment of fresh air through the open window leads to an increase of the mean gas temperature, which reaches its previous levels approximately 13 min after the fire initiation. The TCT-SE thermocouple tree failed $21 \mathrm{~min}$ after the fire initiation. The modest drop in TCT-NW measurements observed at the 35 min mark is owed to the impact of the partial collapse of the free standing wall, supporting the TCT-NW thermocouple tree, on the developing flow and thermal fields.

In Fig. 5, upper layer gas temperatures, measured at a height of $1900 \mathrm{~mm}$, are compared to the standard ISO 834 [6] and Eurocode 1 [18] time-temperature curves. A good qualitative agreement is observed in both thermocouple tree positions; however, the measured gas temperatures are generally lower, by up to $200 \mathrm{~K}$, than the respective standard curves. This observation corroborates the conservative nature of the standard curves, which are known to systematically overestimate the upper layer gas temperature $[14,17]$. 


\subsection{Thermal Behaviour of Wall Assemblies}

The temporal evolution of gas and timber element temperatures across the timber frame and CLT wall assemblies is depicted in Fig. 6. In order to properly characterize the thermal exposure of each wall assembly, measurements of gas temperatures, at a distance of $10 \mathrm{~mm}$ from the exposed wall surface, are also shown. Comparison of gas temperatures measured $10 \mathrm{~mm}$ from the exposed wall surfaces (TF-G-10, CLT-G-10) suggests that, due to the careful positioning of the wood crib fire source, both wall assemblies are exposed to almost identical thermal environments. Despite the fact that gas temperatures exceed $500^{\circ} \mathrm{C}$, the recorded temperatures at the exposed gypsum plasterboard surface (TF-W-0, CLT-W-0) remain below $300^{\circ} \mathrm{C}$ in both cases. Due to the very good fire-resistance characteristics of the gypsum plasterboards owed to gypsum dehydration phenomena, temperatures at the unexposed gypsum plasterboard side (TF$\mathrm{W}-25, \mathrm{CLT}-\mathrm{W}-25)$ are kept constantly lower than $120^{\circ} \mathrm{C}$. The plywood sheathing in the timber frame wall assembly further impedes the heat flow, thus resulting in temperatures that never exceed $60^{\circ} \mathrm{C}$ at the exposed side of the timber stud (TF-W-35) or $30^{\circ} \mathrm{C}$ at its middle span (TF-W78). Due to the lower thickness of the rock wool layer used in the CLT wall assembly and the absence of the plywood sheathing, the exposed side of the CLT (CLT-W-65) reaches somewhat higher temperatures; however, measured values remain consistently lower than $90^{\circ} \mathrm{C}$, thus preventing the onset of charring. Based on a post-fire optical inspection analysis, no charring or cracking is observed in either type of timber element (timber frame, CLT). This observation, combined with the fact that the measured temperature rise at the unexposed sides of the wall assemblies never exceeded $140 \mathrm{~K}$, suggests that both the timber frame and the CLT wall assemblies satisfy the fire resistance "separating function" requirements, with respect to the integrity (E) and insulation (I) criteria, for the entire duration of the fire test (45 min) [2].

Recorded temperature values at the TF-WBP free standing wall assembly (Fig. 7) suggest that the fire protection capability of wood-based panels is worse than that of gypsum plasterboards. As expected, high temperatures are observed at both the exposed sides of the free standing wall; temperatures at the N side (WBP-W-0), directly facing the wood crib and the NW corner of the test compartment where combustion products are accumulated, increase faster than the respective temperatures at the S side (WBP-W-169). However, temperatures at the unexposed sides of both the chipboard (WBP-W-32) and the MDF (WBP-W-137) fire protection layers, as well as the timber stud surface (WBP-W-42, WBP-W-127) never exceed $100^{\circ} \mathrm{C}$. The high thermal stress imposed on the free standing wall, owed to the strongly asymmetric heating on its $\mathrm{N}$ and $\mathrm{S}$ face, resulted in a partial collapse of the $\mathrm{S}$ side, observed approximately $35 \mathrm{~min}$ after fire initiation. 


\subsection{Characteristic Failure Times}

It is well established that the onset of charring is delayed when timber elements are protected by a fire protection cladding; the time to charring initiation depends on the thermal performance of the fire protection material. The thermal behaviour of a fire protected timber element is also affected by the integrity of the fire protection cladding; mechanical failure of the cladding may result in increased charring rates. Failure of the fire protection cladding may occur due to thermal degradation of the material or failure of the fasteners [2, 29]. However, if the fire protection cladding remains intact, the charring rate on the timber element is always lower than the charring rate observed in an unprotected timber element [2].

Correlations proposed in Eurocode 5 [2] allow estimation of two characteristic fire protection failure times, namely "time to failure of the fire protection cladding" ( $\left.t_{f}\right)$ and "time to charring initiation of the timber member" $\left(t_{c h}\right)$. Aiming to quantify the fire protection capabilities of the investigated gypsum plasterboard and wood-based panel claddings, values of these characteristic failure times estimated using the Eurocode 5 correlations (Est.) are compared to the respective fire test observations (Exp.) in Table 2. As expected, the fire behaviour of the gypsum plasterboards claddings is significantly better compared to the fire-resistant wood-based panel claddings. In the case of gypsum plasterboard, no cladding failure or timber member charring is expected to occur during the 45 min duration of the fire test, a fact supported by both Eurocode estimations and experimental observations. On the other hand, significant charring is observed in the timber frame studs of the TF-WBP wall assembly (c.f. Fig. 3), due to the partial collapse of its $\mathrm{S}$ side, protected by the MDF cladding. Estimated values of the time to failure of the fire protection cladding $\left(t_{f}\right)$ are in good agreement with the experimentally observed ones, thus corroborating the good prediction capabilities of the respective Eurocode 5 [2] correlations. The time to charring initiation $\left(t_{c h}\right)$ of the timber frame members in the TF-WBP assembly is assumed to be equal to the time that the temperature of the non-exposed side of each cladding layer (chipboard, MDF) reaches the critical value of $300^{\circ} \mathrm{C}$, a temperature threshold commonly utilized to signify the onset of charring [2]. Also in this case, measured values of the charring onset time are found to be in good agreement with the estimated Eurocode values.

\section{Conclusions}

A full-scale natural fire test was performed aiming to investigate the potential of gypsum plasterboards and wood-based panels as fire protection claddings for light (timber frame) and massive (CLT) timber elements. The test compartment was constructed using a variety of timber 
element and fire protection cladding combinations, enabling, for the first time, a comparative assessment of their fire behaviour when they are simultaneously exposed to the same fire environment. Aiming to achieve realistic fire conditions, a wood crib was used to simulate the fire load; the measured upper gas layer temperatures reproduced well the Eurocode 1 and ISO 834 time-temperature curves for compartment fires. An extensive set of measuring devices was installed in the test compartment to record the time evolution of a range of physical parameters, such as gas temperatures, temperatures at the interfaces between the various wall assembly layers and gas concentrations. The obtained set of detailed measurements can be used for validation of relevant fire simulation tools, appropriate for modelling the fire behaviour of timber construction systems.

Experimental evidence (measured wall surface temperatures, optical inspection after the conclusion of the test) showed that gypsum plasterboards offer better fire protection than woodbased panels. No charring was observed in either the timber frame or the CLT elements protected by gypsum plasterboards; both timber element types retained, for the $45 \mathrm{~min}$ duration of the test, their separating function in the context of fire resistance requirements. In contrast, recorded temperatures and optical evidence (significant charring, partial collapse of the wall) suggested that wood-based panels provided insufficient fire protection to the TF-WBP free standing wall, thus demonstrating their inferior fire protection capability compared to gypsum plasterboards. No vertical wall gypsum plasterboard layer failed, whereas the chipboard fire protection cladding of the TF-WBP wall collapsed approximately $35 \mathrm{~min}$ after fire initiation. Measured values of characteristic failure times, such as time to failure of the fire protection cladding time and onset of timber member charring were compared to respective Eurocode 5 correlations, achieving good levels of agreement, thus corroborating the validity of the respective correlations in realistic fire conditions.

\section{Acknowledgements}

The Greek Wood Association funded the construction of the test compartment. The fire test has taken place in the research facilities of the Greek Fire Academy. The assistance of research and academic personnel of the National Technical University of Athens, i.e. Dr. George Zannis (School of Mechanical Engineering, experimental equipment installation and monitoring), Lecturer Eleftheria Tsakanika and Hon. Professor Panayiotis Touliatos (School of Architecture, design of test compartment) is gratefully acknowledged. 


\section{References}

[1] Pajchrowski G, Noskowiak A, Lewandowska A, Strkowski W. Wood as a building material in the light of environmental assessment of full life cycle of four buildings. Constr Build Mater 2014;52:428-36.

[2] EN 1995-1-2. Eurocode 5, Design of timber structures - Part 1-2: General - Structural fire design. Brussels: European Committee for Standardization; 2004.

[3] Tsantaridis LD, Oestman BAL, Koenig J. Fire protection of wood by different gypsum plasterboards. Fire Mater, 1999;23(1):45-8.

[4] Kolaitis DI, Founti MA. Development of a solid reaction kinetics gypsum dehydration model appropriate for CFD simulation of gypsum plasterboard wall assemblies exposed to fire. Fire Safety J 2013;58:151-59.

[5] Gagnon S, Pirvu C. CLT Handbook, FPInnovations, Special Publication SP-528E, Quebec, Canada, 2011.

[6] ISO 834-1. Fire-resistance tests - Elements of building construction - Part 1: General requirements. Switzerland: International Standards Organization; 1999.

[7] Frangi A, Fontana M, Hugi E, Joebstl R. Experimental analysis of cross-laminated timber panels in fire. Fire Safety J 2009;44(8):1078-1087.

[8] Yang TH, Wang SY, Tsai MJ, Lin CY. Temperature distribution within glued laminated timber during a standard exposure test. Mater Design 2009;30:518-25.

[9] Dagenais C, Osborne L, Benichou N. Full-scale fire performance of cross-laminated timber walls and floors. Proceedings of the $13^{\text {th }}$ International Conference and Exhibition on Fire Science and Engineering; 2013 June 24-26; Windsor, UK. London: Interscience Communications Limited; 2013, p. 1157-68.

[10] Schmid J, Menis A, Fragiacomo M, Bostroem, Just A. The load-bearing performance of CLT wall elements in full scale fire tests. Proceedings of the $13^{\text {th }}$ International Conference and Exhibition on Fire Science and Engineering; 2013 June 24-26; Windsor, UK. London: Interscience Communications Limited; 2013, p. 1143-55.

[11] Teibinger M. Fire resistance of timber constructions - Evaluation of improved design models. Proceedings of the $13^{\text {th }}$ International Conference and Exhibition on Fire Science and Engineering; 2013 June 24-26; Windsor, UK. London: Interscience Communications Limited; 2013, p. 1465-76. 
[12] Park SH, Manzello SL, Bundy MF, Mizukami T. Experimental study on the performance of a load-bearing steel stud gypsum board wall assembly exposed to a real fire. Fire Safety J 2011; 46(8):497-505.

[13] Welch S, Jowsey A, Deeny S, Morgan R, Torero JL. BRE large compartment fire tests Characterising post-flashover fires for model validation. Fire Safety J 2007;42(8):548-67.

[14] Wald F, Chlouba J, Uhlır A, Kallerova P, Stujberova M. Temperatures during fire tests on structure and its prediction according to Eurocodes. Fire Safety J 2009;44(1):135-46.

[15] Hwang CH, Lock A, Bundy M, Johnsson E, Ko GH. Studies on fire characteristics in overand underventilated full-scale compartments. J Fire Sci 2010;28(5):459-86.

[16] Moinuddin KAM, Al-Menhali JS, Prasannan K, Thomas IR. Rise in structural steel temperatures during ISO 9705 room fires. Fire Safety J 2011;46(8):480-96.

[17] Hakkarainen T. Post-flashover fires in light and heavy timber construction compartments. Journal Fire Sci. 2002;20(2):133-75.

[18] EN 1991-1-2, Eurocode 1: Actions on Structures, Part 1-2: General Actions on Structures Exposed to Fire. Brussels: European Committee for Standardization; 2002.

[19] Frangi A, Bochicchio G, Ceccotti A, Lauriola MP. Natural Full-Scale Fire Test on a 3 Storey XLam Timber Building. Proceedings of the $10^{\text {th }}$ World Conference on Timber Engineering; 2008 June 2-5, Miyazaki, Japan.

[20] McGregor C, Hadjisophocleous G, Craft S. Contribution of cross laminated timber panels to room fires. Proceedings of the $13^{\text {th }}$ International Conference and Exhibition on Fire Science and Engineering; 2013 June 24-26; Windsor, UK. London: Interscience Communications Limited; 2013, p. 1453-64.

[21] Lennon T, Hopkin D, El-Rimawi J, Silberschmidt V. Large scale natural fire tests on protected engineered timber floor systems. Fire Safety J 2010;45(3):168-82.

[22] Wolfe AJ, Mealy CL, Gottuk DT. Fire Dynamics and Forensic Analysis of Limited Ventilation Compartment Fires Volume 1: Experimental, Grant No. 2007-DN-BX-K240. Maryland: Hughes Associates Inc., 2009.

[23] Mackay D, Barber T, Yeoh GH. Experimental and computational studies of compartment fire behaviour. Build Environ. 2010;45(12):2620-8.

[24] ISO 1716. Reaction to fire tests for building products - Determination of the Heat of Combustion. Switzerland: International Standards Organization; 2002.

[25] DiNenno PJ, Drysdale D, Beyler CL, Walton WD, Cruster RLP, Hall JR et al. S.F.P.E. Handbook of Fire Protection Engineering. $3^{\text {rd }}$ Edition. USA: National Fire Protection Association; 2002. 
[26] Tewarson A. Fully developed enclosure fires of wood cribs. Proceedings of the $20^{\text {th }}$ International Symposium on Combustion; 1984 August 12-17; Michigan, UK. Elsevier; 1985, p. 1555-66.

[27] Tang F, Hu L, Wang Q, Lu KH, Yang LZ. An experimental investigation on temperature profile of buoyant spill plume from under-ventilated compartment fires in a reduced pressure atmosphere at high altitude. Int J Heat Mass Tran, 2012;55(21-22):5642-49.

[28] Luo M. Effects of radiation on temperature measurement in a fire environment. J Fire Sci $1998 ; 15: 443-61$.

[29] Koenig J. Structural Fire Design According to Eurocode 5 - Design rules and their background. Fire Mater 2005;29:147-63.

[30] Broheza S, Delvosalle C, Marlair G. A two-thermocouples probe for radiation corrections of measured temperatures in compartment fires. Fire Safety J 2004;39(5):399-411.

[31] Brundage AL, Donaldson AB, Gill W, Kearney SP, Nicolette VF, Yilmaz N. Thermocouple response in fires, Part 1: Consideration in flame temperature measurements by a thermocouple. $\mathrm{J}$ Fire Sci 2011;29:195- 211.

[32] Whitaker S. Forced convection heat transfer correlations for flow in pipes past flat plates, single cylinders, single spheres and for flow in packed beds and tube bundles. AICHE J 1972;18:361-71.

[33] Brundage AL, Donaldson AB, Gill W, Kearney SP, Nicolette VF, Yilmaz N. Thermocouple response in fires, Part 2: Validation of virtual thermocouple model for fire codes. J Fire Sci 2011;29:213- 26.

[2] Östman B, Mikkola E, Stein R, Frangi A, König J, Dhima D et al. Fire safety in timber buildings: Technical guideline for Europe. SP Report 2010:19; 2010

[34] Kolaitis DI, Asimakopoulou EA, Founti MA, Touliatos P. Experimental investigation of the fire behaviour of contemporary timber construction techniques (in Greek). Greek Fire Academy Report; 2011.

\section{Appendix A. Correction methodology for gas temperature measurement uncertainties.}

When a bare bead thermocouple is used to measure gas temperatures at the interior of a fire compartment, the obtained values are not fully representative of the actual local gas temperature, due to a variety of physical phenomena, such as radiative heat transfer between the bead and the surrounding bodies (gas, wall surfaces), conductive heat transfer along the thermocouple wire or 
the transient response of the bead [13, 23, 28, 30]. The relative impact of radiative heat transfer is significantly higher compared to other sources of error; as a result, the latter are typically neglected $[13,28]$. A bare bead thermocouple located at the upper gas layer may result in a temperature reading lower than the actual gas temperature, due to radiative heat losses to the surrounding cold bodies, such as the compartment walls or the low temperature ambient air entering the compartment through the openings. On the other hand, a bare bead thermocouple located at a low height may result in temperature readings higher than the actual gas temperature, due to radiative heat gains from the surrounding hot bodies, such as the flame or the high temperature upper gas layer. Aiming to mitigate the impact of errors associated with radiative heat transfer, a variety of bare bead thermocouple "measurement correction" methodologies has been developed [13, 23, 28].

In this study, 14 chromel type $\mathrm{K}$ bare bead thermocouples were selected to monitor gas temperatures inside the test compartment, since they exhibit good dynamic response characteristics in the fast changing thermal field inside the fire compartment [31]. Aiming to mitigate the gas temperature measurement errors associated with radiative heat transfer, a postprocessing "correction" methodology, proposed by Welch et al. [13], was used. The correction methodology is based on the solution of the heat balance equation for the thermocouple bead, which results in Equation (A.1), where $T_{\text {gas }}(\mathrm{K})$ is the actual gas temperature, $T_{T C}(\mathrm{~K})$ is the temperature value measured by the thermocouple, $T_{S}(\mathrm{~K})$ is the "effective" temperature of the bead's surroundings, ETC is the bead's emissivity, $\sigma=5.67 \times 10^{-8} \mathrm{~W} / \mathrm{m}^{2} \mathrm{~K}^{4}$ is the Stefan-Boltzmann constant and $h_{T C}\left(\mathrm{~W} / \mathrm{m}^{2} \mathrm{~K}\right)$ is the convective heat transfer coefficient. The latter was estimated to be approximately $190 \mathrm{~W} / \mathrm{m}^{2} \mathrm{~K}$, using a correlation for spherical bodies immersed in a flow [32] and taking into account that typical velocities developed in compartment fires range between 0.5 $\mathrm{m} / \mathrm{s}$ and $2.0 \mathrm{~m} / \mathrm{s}$ [30]. The thermo-physical properties of the surrounding gas (e.g. density, conductivity, dynamic viscosity), assumed to be air, were estimated using temperature-dependent correlations [25]. A bead emissivity value of 0.9 , corresponding to a significantly oxidized thermocouple bead surface [33], was used.

$$
T_{g a s}=\frac{\varepsilon_{T C} \sigma}{h_{T C}}\left(T_{T C}^{4}-T_{S}^{4}\right)+T_{T C}
$$

Aiming to approximate the radiation field at the position of each thermocouple, the "effective" temperature of its surroundings $\left(T_{S}\right)$ is estimated by employing temperature measurements obtained in all the other $(N)$ thermocouples that are present in the respective thermocouple tree (Equation A.2). A weighting factor $\left(w_{i}\right)$ is used to estimate the radiative influence from each " $i$ " 
thermocouple location to the examined position, by taking into account their relative distances, the effective emissivity of the gas surrounding the " $i$ " thermocouple and the radiative transmission properties of the intervening participating medium, characterised by an extinction coefficient. The extinction coefficient was assumed to be unity [13], since the fire test corresponded to an under-ventilated fire and the soot yield of the wood cribs can be assumed to be less than $2 \%$ [25].

$$
T_{S}=\left(\sum_{i=1}^{N} w_{i} T_{\text {gas }, i}^{4}\right)^{\frac{1}{4}}
$$

In order to determine the "corrected" gas temperature at each thermocouple location $\left(T_{\text {gas }}\right)$, the system of Equations (A.1) and (A.2) was solved using an iterative method, by employing a relaxation factor (equal to 0.22 ). The time evolution of the calculated "relative error" in gas temperature measurements, expressed via $\left(T_{\text {gas }}-T_{T C}\right) / T_{T C}$, is shown in Figure A.1, for all thermocouple locations in both thermocouple trees (TCT-NW, TCT-SE). As expected, "corrected" gas temperatures are higher than the measured values in thermocouples located higher than $1000 \mathrm{~mm}$, whereas they are lower in thermocouples located at lower heights (less than $500 \mathrm{~mm})$. Mean error values are higher at lower heights $(-7.2 \%$ at $50 \mathrm{~mm})$ compared to middle $(0.02 \%$ at $1000 \mathrm{~mm})$ or high heights $(3.71 \%$ at $1900 \mathrm{~mm})$. Maximum error values are observed at the lower measuring locations of TCT-NW, due to the accumulation of hot gaseous products at the NW corner of the test compartment. 


\section{Figure Captions}

Figure 1. Top (left) and side (right) sections of the test compartment; locations of main measuring devices.

Figure 2. Layout of the timber frame (left), CLT (middle) and wood-based panel protected timber frame (right) wall assemblies and relevant thermocouple positions.

Figure 3. Post-fire photograph of the western timber frame and the wood-based panel protected timber frame wall assemblies.

Figure 4. Gas temperatures measured at the TCT-SE (top) and the TCT-NW (bottom) thermocouple trees.

Figure 5. Comparison of upper layer gas temperatures to standard time-temperature curves.

Figure 6. Time evolution of gas and wall temperatures across the timber frame (top) and CLT (bottom) wall assemblies.

Figure 7. Temporal evolution of wall temperatures across the wood-based panel protected timber frame wall assembly.

Figure A.1: Time evolution of calculated "relative error" in gas temperature measurements, for the TCT-SE (top) and the TCT-NW (bottom) thermocouple tree. 